\title{
Obras duradouras
}

António Faria-Vaz*

\section{Sobre a Construção de Obras Duradouras}

Quanto tempo

Duram as obras? Tanto

Quanto o preciso pra ficarem prontas.

Pois enquanto dão que fazer

Não ruem.

Convidando ao esforço

Compensando a participação

A sua essência é duradoura enquanto

Convidam e compensam.

As úteis

Pedem homens

As artísticas

Têm lugar pra a arte

As sábias

Pedem sabedoria

As destinadas à perfeição

Mostram lacunas

As que duram muito

Estão sempre pra cair

As planeadas verdadeiramente em grande

Estão por acabar.

..

Bertold Brecht, in 'Lendas, Parábolas, Crónicas, Sátiras e outros Poemas"

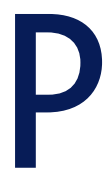

roduzir uma revista científica é uma obra que necessita de inúmeros artífices. Dos inventores da matéria prima, verdadeiros arquitectos da ciência, aos artífices que a apreciam e lhe sugerem aperfeiçoamentos, dos revisores, até aos que procuram um lugar e um momento para as expor aos nossos olhos, os editores. Uma obra, como esta, é portanto, a resultante de um trabalho de equipa, de um esforço comum e conjugado.

Quanto tempo dura uma obra escrita, quantos a lêem

*Director da Revista Portuguesa de Clínica Geral e durante quanto tempo é expectável que um artigo científico seja lido e citado após a sua publicação?

Quanto tempo dura a memória de um corpo editorial que produziu um determinado número desta ou de qualquer outra revista?

Embora não procuremos respostas para todas as questões, algumas delas são abordadas em estudos bibliométricos que temos em gestão e cuja publicação se deseja para breve.

No entanto, o que procuramos com aquelas questões é apenas dar o mote para um novo ciclo, que ora se inicia, com uma nova equipa editorial.

Este será, portanto o último número produzido por esta equipa.

Foram três anos de intenso trabalho, de emoção e de compromisso com os objectivos traçados - «contribuir para o desenvolvimento da especialidade de Medicina Geral e Familiar e para a melhoria dos cuidados de saúde primários».

Como equipa, sentimo-nos gratificados, pois a Revista deu-nos, antes de mais, a oportunidade de prestarmos um serviço público. Sentimo-la como a possibilidade de cumprir um dever ético: divulgar o conhecimento científico e dignificar a nossa especialidade, a Medicina Geral e Familiar.

Palavras de circunstância, dirá o leitor.

Mesmo que fossem, não deixariam de exprimir o sentimento de uma equipa editorial que soube construir esta revista sem partir de experiência própria, antes aprendendo ao fazer, sem nunca esmorecer, sempre com vontade de superar o que acabara de realizar.

Os leitores puderam ajuizar-nos.

Resta-nos a satisfação pelo trabalho realizado mas que não conclui esta obra grande e, por isso mesmo, passamos hoje o testemunho ao novo corpo editorial, dirigido pela Dra. Raquel Braga, cujas qualidades científicas, clínicas e um profundo conhecimento da actividade de produção editorial dispensam elogios e são o garante de um futuro ainda melhor.

Boas leituras!... 